Agricultural and Resource Economics: International Scientific E-Journal

http://are-journal.com

JEL: Q01, Q12, J01, J08

Hai Ninh Nguyen Thi

Vietnam National University of Agriculture

Vietnam

\title{
VIETNAM LABOUR POLICIES AND ITS IMPACT ON RURAL WAGES: AN EXPERIENCE FROM HIRED FARM LABOURERS IN THE RED RIVER DELTA
}

Purpose. The purpose of this article is to understand how Vietnamese policies for labour impacting on wage of rural labourers in agricultural sector. To do that, the paper particularly pays attention on analyzing wage of hired farm labourers in the Red River Delta region, the rice basket of Vietnam.

Methodology / approach. Analyzing the above-mentioned impact of Vietnamese policies was performed by using data surveyed from 150 hired farm labourers in the Red River Delta of Vietnam. The survey on wages of rural labourers was conducted in Bac Ninh, Thai Binh and Hai Duong which are the three typical agricultural production areas in the Red River Delta in 2019. In this survey, the author interviewed 150 people who work as hired labourers in rice cultivation in Bac Ninh, clam farming in Thai Binh and pig raising in Hai Duong. The sample was randomly drawn among farm households which hire labourers in these provinces. This sample was divided into 2 groups of female and male labourers. The main purposes of this survey were to gather both qualitative and quantitative data on hired labourers including: age, gender, education level, money wage, wage in kind and other remunerations that they received from employers. Information relating to their participation in social insurance and vocational training were also collected like: number of years involving in social insurance; money that they used to purchase social insurance; frequency and time spending in vocational training courses. The personal interviews using a standard questionnaire with open and close questions were implemented separately with male and female hired farm labourers. They were interviewed in different places to ensure that their responses do not affect others. After checking for missing values, the author used the following methods: frequency distribution with mean and standard deviation for a description of respondents; cross tabulation and T-test were also used to test for differences in proportions and significant difference between groups; a linear regression model was applied to examine impact of wage regulation, social insurance and vocational training policies on wage of hired labourers in agricultural production (dependent variable was average money wage per month, it was estimated by sum of money wage and other remunerations that a labourer gets each month; independent variables were age, gender, education level and dummy variables which represented labourers' participation in mentioned labour policies).

Results. Among policies relating to agricultural sector, the ones about minimum wage and vocational training statistically impact the most on labour wage. Longer time of vocational training brings an additional 3 USD to a labourer's monthly wage. Being supported by the policy of minimum wage, labourers can achieve higher wage when negotiating with employers. The author found that wage of a labourer who is aware of this policy is about 5 USD higher than that of others. Meanwhile, social insurance policies do not impact on wage of rural farm labourers. It is stated in the Labour Code that a part of social insurance fee of a contracted labourer is paid by his/her employer. However, hired agricultural labourers usually are excluded, because they mostly work under verbal agreements which are not specified by the Code. This loophole in the Labour Code 


\section{Agricultural and Resource Economics: International Scientific E-Journal}

http://are-journal.com

need to be corrected in the future.

Originality / scientific novelty. Despite the fact that industrialization process is rapidly developing in recent years, rural labour force still contributes a remarkable proportion in the Red River Delta region of Vietnam. The transferring skilled and young labourers from farm to off-farm sectors, from rural to urban areas leads to the existence of un-skilled and old-age labourers for agricultural production. This labour force is working in the poor condition with unstable and low wage jobs. However, they are not much concerned by labour policies and there is still a gap in research on their wage. Therefore, this study takes the advance to shed the light on the impact of labour policies on wage of rural farm labourers as well as to propose recommendations to adjust labour policies regarding this issue.

Practical value / implications. The author identifies that attending vocational training and understanding of minimum wage will increase the chance for labourers to obtain higher wage.

Key words: labour policies, wage, hired farm labour, Red River Delta, Vietnam.

Introduction and review of literature. Despite the fact that trend of urbanization is increasing in Vietnam in recent years, there are still $67.8 \%$ of the labour force concentrated in rural areas [1]. Rural labourers are those in the labour force, engaged in all activities of rural economy such as cultivation, animal husbandry, forestry, fisheries, handicrafts and services in rural areas. In this force, agricultural labourers including cultivation, animal husbandry, forestry and aquaculture capture the largest proportion and play the most important role. This is the main force producing food for society and ensuring national food security. However, rural labourers are facing many disadvantages related to the poor quality of employment, low income as well as lack of the Government's support [2].

In the recent years, policies for workers in general and for rural labourers in particular have always been a concern of the Vietnamese Government. Basically, these policies are issued in order to create stable jobs and increase incomes for rural workers. If the minimum wage and social insurance policies ensure that workers have a certain level of income which is enough for their living, the vocational training policy equips them with the necessary skills to seek and maintain their jobs. Nevertheless, the relationship between wage and living expenses of Vietnamese workers has not changed much so far, and almost all workers are unable to live with their monthly wage. In addition, low wages paid to labourers make them less motivated to work. Consequently, Vietnam labour productivity is lower than other Southeast Asian countries and the economic growth rate has slowed down [3]. Looking at the specific figures, the average wage of labourers in Vietnam increased 1.5 times from 2007 to 2015 . Average wage increased rapidly until 2010 but slowed significantly in the period of 2010-2015 reflecting the decline in economic growth [4]. This decline is more evident in rural areas when the wages of labourers in urban areas are about 100 USD higher than that of rural labourers. Moreover, rural labourers are often not trained so that they are observed mostly in agricultural sector or in other informal economic sectors resulting in unstable jobs and low wages [5].

The Red River Delta region of Vietnam has the second lowest proportion of agricultural labour after the Southeast. Moreover, this proportion tends to reduce stronger than the other 5 regions of the whole country. It decreases continuously from 
2016 to 2018 with average $1.8 \%$ reduction rate each year. This reduction is due to the shifting of agricultural labour in the whole country and specifically in the Red River Delta toward non-agricultural section inside rural area as well as out of it. This shifting of the economic structure is heading in the right direction. Especially, the surveyed results of the General Statistical Office (GSO) show the shifting trend mainly toward industrial field. Typical examples of this trend are several provinces in the Red River Delta such as Bac Ninh, Hai Duong and Thai Binh. Strong and fast shifting in such provinces is mainly due to the foundation of numerous industrial zones in the area [6]. The labour movement from agriculture to non-agriculture results in a lack of skilled labourers in agricultural production. The rest of the workers in this sector are mostly unskilled and older laborers, they are facing with low income and unstable jobs. For this reason, the Red River Delta is selected to identify whether Vietnamese labour policies have impact on improving wage of agricultural labourers in this region.

International labour organization defined wage as "remuneration or earnings, however designated or calculated, capable of being expressed in terms of money and fixed by mutual agreement or by national laws or regulations, which are payable in virtue of a written or unwritten contract of employment by an employer to an employed person for work done or to be done or for services rendered or to be rendered" [7]. Earnings (wages and salaries) is the concept of earnings as applied in wages statistics, relates to remuneration in cash and in kind paid employees for time worked or work done together with remuneration for time not worked, such as annual vacation and other paid leave or holidays. Earnings exclude employers' contributions in respect of their employees paid to social security and pension schemes and also the benefits received by employees under these schemes. Earnings also exclude severance and termination pay [8]. There are several types of wage as followings [9]:

Piece Wages: Piece wages are the wages paid according to the work done by the worker. To calculate the piece wages, the number of units produced by the worker are taken into consideration.

Time Wages: If the labourer is paid for his services according to time, it is called as time wages.

Cash Wages: Cash wages refer to the wages paid to the labour in terms of money. The salary paid to a worker is an instance of cash wages.

Wages in Kind: When the labourer is paid in terms of goods rather than cash, is called the wage in kind. These types of wages are popular in rural areas.

Contract Wages: Under this type, the wages are fixed in the beginning for complete work.

With respect to these types of wage, wages in kind and contract wages are commonly observed in agricultural production in rural Vietnam due to the seasonality of this sector. Nonetheless, cash wage is also popularly used as it is preferred by rural workers.

In general, wage levels result from individual and collective negotiations between the employees (and their representatives) with the management (and the 
owners) of firms. In addition, laws, policies and negotiations decide wages. A stimulus-oriented policy or a labour support policy might increase wage in labour market. In the low wage sector as agriculture, policies for employees play more important role in protecting wage rates as well as other remunerations. Moreover, jobs in agricultural sector in a developing country like Vietnam is known as unstable due to low-skilled workers. Therefore, wage regulation, social insurance and vocational training are considered to have impact on wage of rural labourers in this country (Fig. 1).

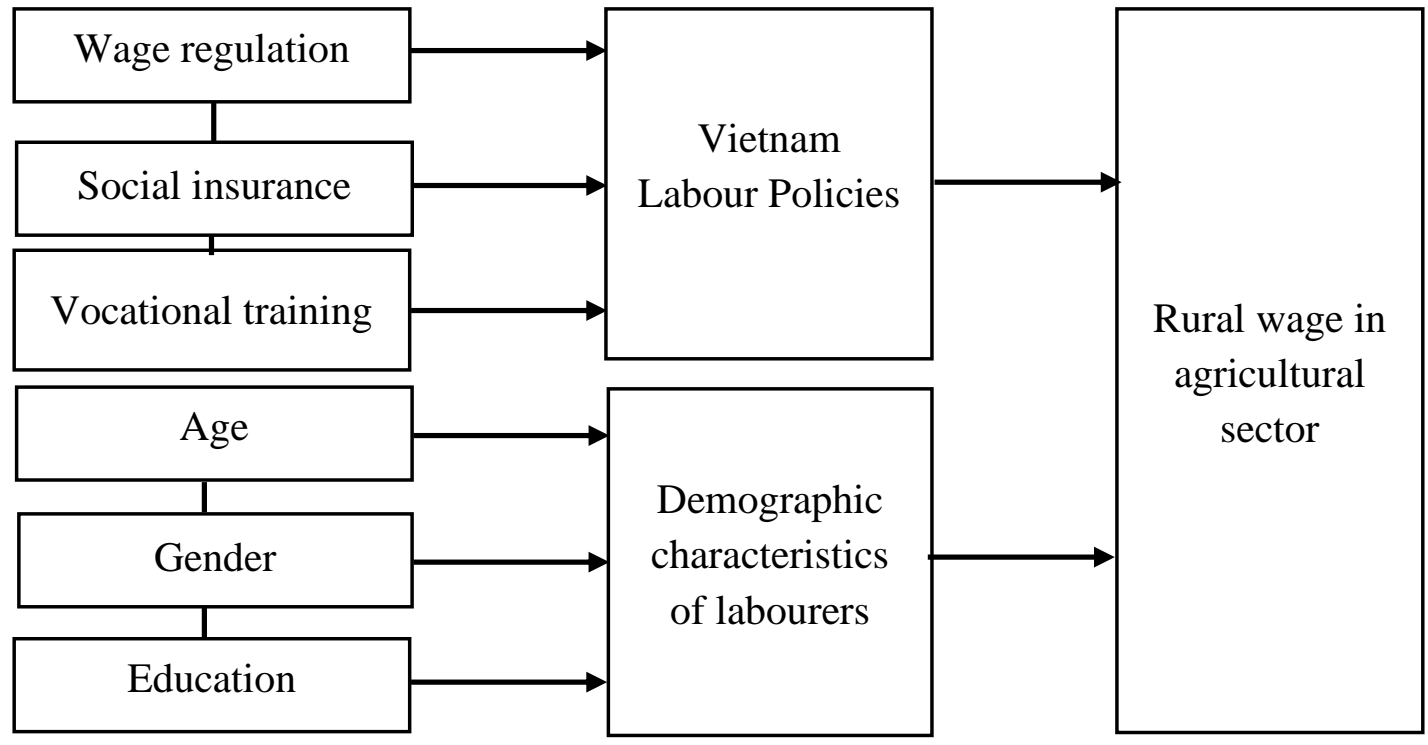

Fig. 1. Determinants of rural wage in agriculture

Source: drawn by the author based on literature review.

Employers pay wages to employees usually depending on working time and/or on results (production made or objectives reached). Individual wage often depends on occupied position as well as on education, cumulated experience and seniority. However, in Vietnam rural areas where proportion of female and old-aged laborers is quite high, wages also depend on gender and age of them.

The purpose of the article is to identify the impact of Vietnam labour policies on wage of hired farm labourers in agricultural sector at the Red River Delta. In other words, the article attempts to shed the light on the influence of Vietnam labour policies on improving wage for rural labourers. In order to address this goal, in the next section the author reports material and methodology.

Methodology. As mentioned earlier, the author based on primary data collected from 150 hired farm labourers in three provinces of the Red River Delta to examine the impact of Vietnam labour policies on their wages. The primary data was analyzed by different statistical methods and applied for estimating a linear regression model as: $\mathrm{Y}_{\text {(Average wage) }}=\mathrm{a}+\mathrm{b}_{1} \cdot \mathrm{X}_{1 \text { (Gender) }}+\mathrm{b}_{2} \cdot \mathrm{X}_{2 \text { (Age) }}+\mathrm{b}_{3} \cdot \mathrm{X}_{3 \text { (Education) }}+\mathrm{b}_{4} \cdot \mathrm{X}_{4 \text { (Vocational training) }}+$ $\mathrm{b}_{5} \cdot \mathrm{X}_{5 \text { (Social insurance) }}+\mathrm{b}_{6} \cdot \mathrm{X}_{6 \text { (Minimum wage) }}$. In addition to the field survey, the author also applied desk research method to review Labour code and labour policies issued by the Vietnamese Goverment. The combination of secondary and primary information helped the author to identify multiple aspects of Vietnamese Labour code and its 


\section{Agricultural and Resource Economics: International Scientific E-Journal}

http://are-journal.com

impacts on wage of farm labourers in agricultural sector.

Results and discussion. In this section, the author firstly provides an overview of Vietnamese Government policies for labour in general. Secondly, the author describes the statistical information of hired farm labourers who were interviewed in the study area. Thirdly, the author analyzes wage of hired farm labourers in terms of wage in cash and of their participation in some labour policies. Lastly, a linear regression model is presented to quantify the impact of labour policies on hired farm labour wage.

Overview of Vietnam labour policies. Minimum wage. Vietnam first set a statutory minimum wage in 1992 that exclusively applied to foreign companies. Over time, it also established a minimum wage for domestic firms. The country's current minimum wage system was introduced in 2006. Under this system, minimum wages vary according to location and sector of employment. Prior to 2012, separate rates were set for general government employees (i.e. staff of the government and public service units like schools and hospitals), for private domestic firms (including stateowned enterprises) and for foreign companies as well as for four broadly defined regions [10]. The four different minimum wage regions are supposed to reflect the cost of living in each area (Table 1).

Description of the four minimum wage regions in Vietnam

Table 1

\begin{tabular}{|c|l|}
\hline Regions & \multicolumn{1}{|c|}{ Description of region } \\
\hline 1 & $\begin{array}{l}\text { Big provinces and cities with much developed economies (Hanoi, Ho Chi Minh } \\
\text { city, Bac Ninh province) }\end{array}$ \\
\hline 2 & $\begin{array}{l}\text { Provinces and suburban cities with relatively developed economies (Hai Duong } \\
\text { province) }\end{array}$ \\
\hline 3 & $\begin{array}{l}\text { Provinces and cities with good economies but lower than region 2 (Thai Binh } \\
\text { province) }\end{array}$ \\
\hline 4 & Province and cities with undeveloped economies (Mountainous provinces) \\
\hline
\end{tabular}

Source: complied by the author based on reviewing Vietnamese Labour Code, 2019.

Region 1, including Hanoi and Ho Chi Minh City, has the highest minimum wage, while region 4, which is for rural areas, has the lowest one [11]. Since 2016, the Vietnamese Government started to apply the minimum wage policy for these four regions. Based on this policy, workers working in region one are paid not lower than 170 USD per month; workers working in region two are paid not lower than 150 USD per month; workers working in region three are paid not lower than 130 USD per month; workers working in region four are paid not lower than 117 USD per month [12]. The minimum wage is annually adjusted by the higher rate comparing inflation rate. In 2019, the minimum wage was increase by $6.5 \%$.

In comparison with minimum wage in many OECD countries, Vietnam's general government sector minimum wages are low. Nonetheless, the remainder of the labour market has different situation. Across the four regions, the average ratio of the regular minimum wage to the mean wage is $50 \%$ for workers outside the general government sector. The average ratio of the minimum to the median wage outside this sector is $58 \%$. Both numbers are among the highest statutory minimum wage 
"bites" found anywhere in the world and are only exceeded by a small number of countries in either the OECD region. Thus outside the general government sector, the ratio of the statutory minimum to the median wage appears relatively high [10].

Regular Payments. In Chapter 6 of Vietnamese Labour Code, regular payments are mentioned in the forms of hourly wage, daily wage, weekly wage, or monthly wage. Basically, an employer is entitled to choose his or her wage of wage payment. Moreover, the wage can be paid based on the quantity of products or on piece-work. Nevertheless, the employer need to have the agreement of employees on the form of payment and maintain this form in a long duration.

One Day off in Seven, Leave, Breaks. The Article 110 of Vietnamese Labour Code regulates that an employee has a right to have at least one day off per week. The weekly day off can be arranged on Sunday or another day of the week depending on the employer's schedule. Additionally, the Labour Code also regulates employee's leave including annual leave, leave for personal reasons, and maternity leave.

Social insurance policies. Social insurance can be understood as the provision of social security benefits financed by contributions, which are normally shared between employers and workers with, perhaps, government participation in the form of a supplementary contribution or other subsidy from the general revenue [13]. Article 34, Constitution of the Socialist Republic of Vietnam states: "Citizens have the right to social security". In the social security policy system, social insurance is the main pillar, the functions of which are minimizing risks, support to people in compensating or partially replacing for their income when they have to face the risks (illness, losing job or working capacity), reducing pressure on the social assistance system. Thus, increasing the social insurance coverage is the measure for this country to strengthen its competitiveness in the global market [14]. The Government is trying to find solutions to facilitate Vietnam citizens in accessing and participating in social insurance. However, Vietnamese Labour Code regulates the participation in compulsory social insurance for employees working under labour contracts but not for those are freelancers working in informal economic sectors, especially in agriculture.

The Labour Code states that employees must participate in compulsory social insurance if they work under permanent contracts or contracts with working period of at least 3 months. Employers, including entrepreneurs, cooperatives, business individuals, cooperative groups, other organizations and individuals whichever hire and pay wage to their employees, are also required by the Code to participate in compulsory social insurance. The voluntary social insurance is for the working age population working without any contract.

Vocational training policies. Before 2000, vocational training in Vietnam was mainly provided to farmers with agriculture skills and the youth who were not able to go to the higher education. Since then, rapid urbanization and industrialization has led to the conversion of agricultural land to residential areas and industrial zones that threatens livelihoods of displaced farmers. Vocational training for displaced farmers have become an urgent issue both within rural areas and increasingly for the 
Government. This had led to a number of Government driven initiatives such as the issuance of the decision 81/2005/QĐ-TTg on short-term vocational training for rural labourers, decision 103/2008/QĐ-TTg directly targeted youth in vocational training and self-employment creation for the period 2008-2015 [15]. However, after several years these policies could not change much skill of rural labour force, lacking in professional/technical qualifications of a numerous labourers has been more and more serious [16].

Economic development of the Red River Delta. In recent years, the economic structure of the Red River Delta has changed towards increasing GDP of industrial and service sectors and decreasing GDP of agricultural sector. Up to 2012, agricultural production only contributed about $10 \%$ to the GDP of the whole region while industrial sector showed its superior contribution to the GDP (45\%) in comparing to service sector (Fig. 2).

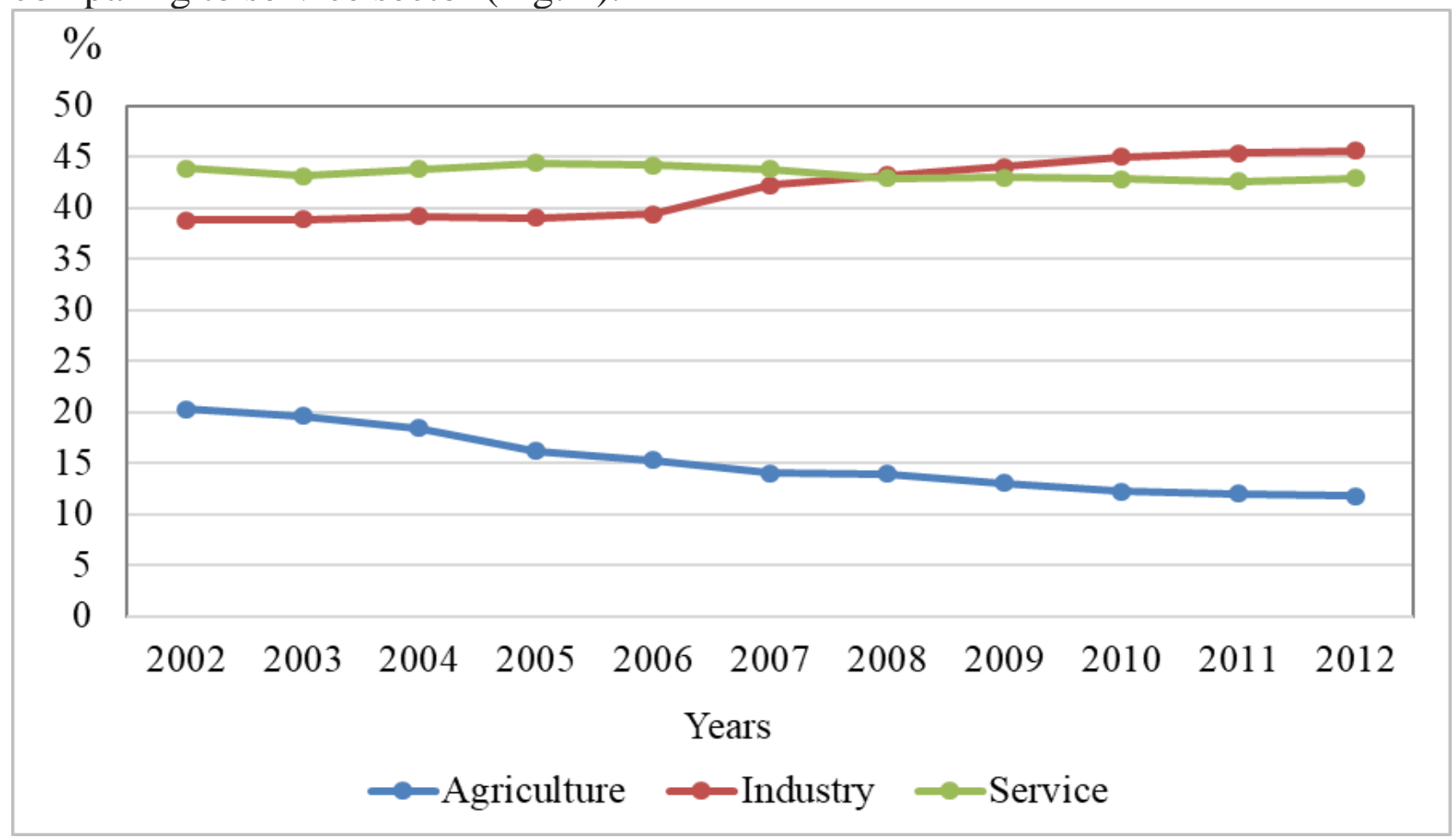

Fig. 2. Economic structure of the Red River Delta

Source: complied by the author based on Vietnam General Statistical Office, 2019.

It can be said that this change of the economic structure is adaptable with the trend of industrialization. However, this change was not the same among provinces of the delta. Bac Ninh is the most outstanding with over $95 \%$ of its GDP created by industrial sector while agriculture contributes only $1 \%$. Whereas, agriculture in Thai Binh still occupies rather considerable amount in the provincial GDP (about 22\%). Among the Red River Delta, Thai Binh is also the province with highest amount of GDP contributed by agriculture. This figure indicates that agricultural sector is still important in the economic growing of Thai Binh. In Hai Duong province, agricultural sector contributes $10.6 \%$ of the provincial GDP, which equals to the average contribution of agriculture in the whole region. Similarly, with Bac Ninh, the industrialization speed in Hai Duong is rather high with $58 \%$ of the total provincial 
GDP contributed by industrial sector. Therefore, Bac Ninh, Hai Duong and Thai Binh are the 3 provinces having typical characteristics of changing process from agricultural to industrial economy in the Red River Delta region.

Description of hired farm labour in the studied areas. Age. Common age of hired labourers in farm households is in range of 40 to 55 years old (Fig. 3). In this age, they have less chance to find non-farm jobs far from home. Therefore, working for other farm households in their own villages or communes is their prior option with the purpose of being able to take care of their own children, parents, fields and to get additional income from hired works. This option is observed in all hired labourers working for the 3 farm household groups of rice production, pig farming and clam farming. With this purpose, the hired farm labourers tend to stick with certain farm households for long time. They want to have stable working location every season. For the farm households, they also want to hire experienced labourers who have worked for them for long time in order to easily negotiate work amount, wage and other conditions.

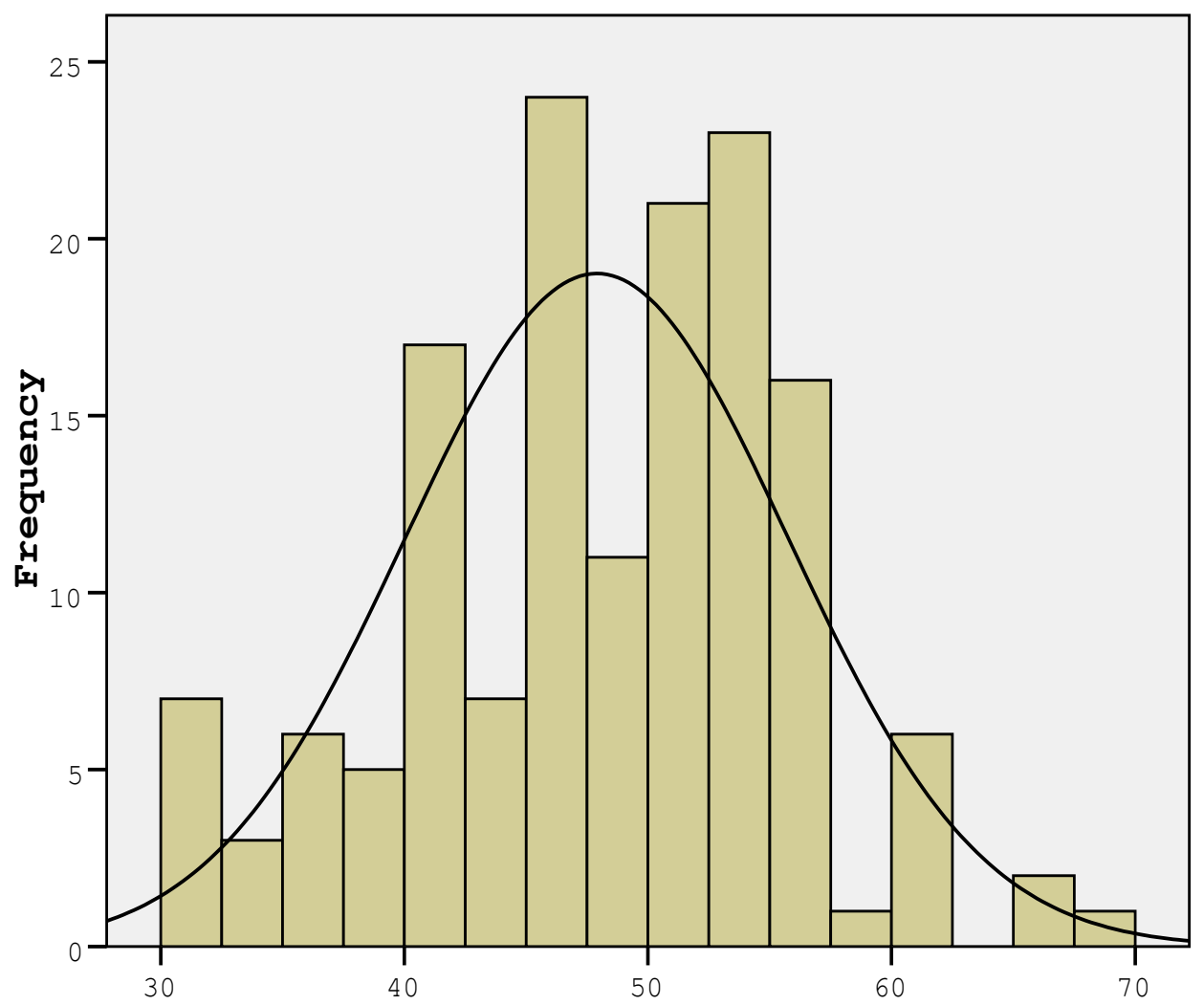

Fig. 3. Age distribution of hired farm labour

Source: complied by the author based on hired farm labour survey in 2019.

Working experience. Fig. 4 illustrates the distribution of hired farm labourers according to time period that they have worked for current farm households (at surveying moment). There were $69 \%$ of the surveyed paid labourers who answered that they had been working for the current households for 2 to 4 years. Some even had worked for over 5 years $(12 \%)$. These figures indicate a close bond between the hired labourers and the farm households. In social aspect, this bond may come from the relationship of relatives or neighborhood because both are living in the same 
locale. In economic aspect, knowing each other helps to reduce dealing cost, supply and demand to meet up easier. Therefore, the labour market in rural area works better.

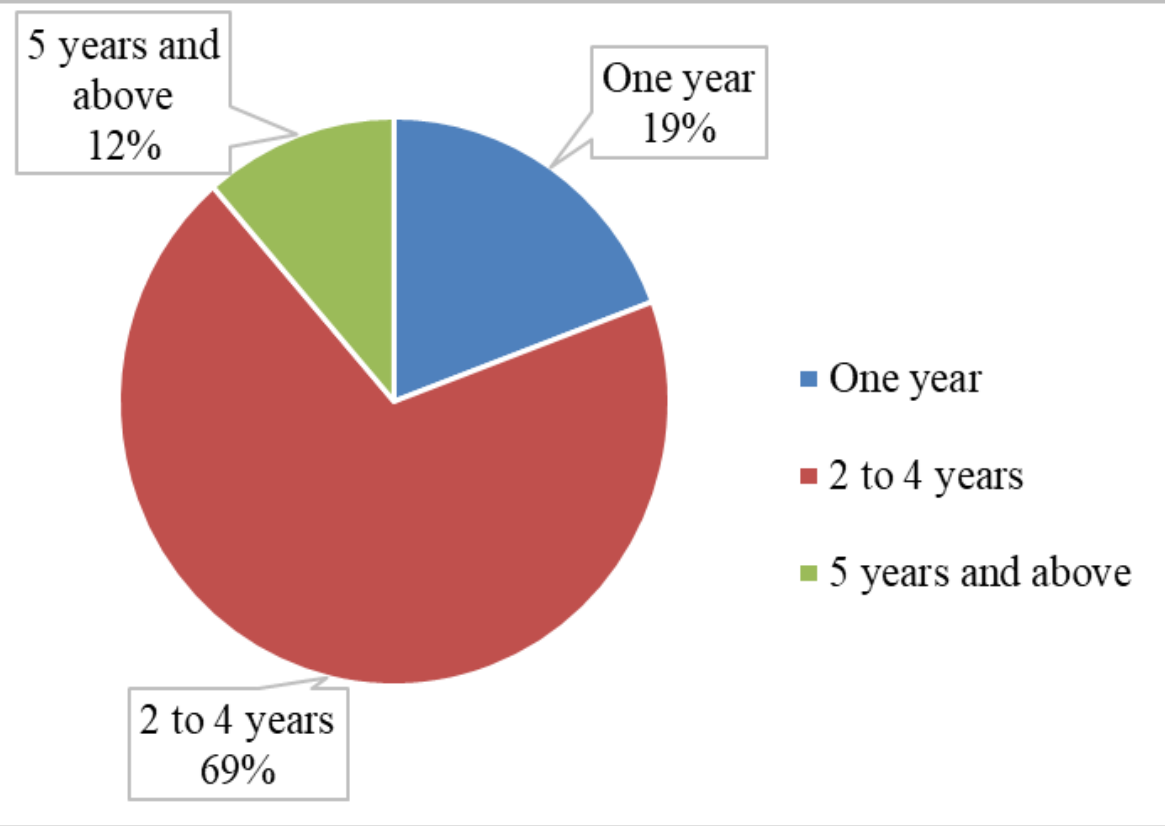

Fig. 4. Distribution of hired farm labourers by working years

Source: complied by the author on the basic of hired farm labour survey in 2019.

Gender. Recent studies identified that the Red River Delta is the only region in Vietnam where the proportion of female labourers is higher than the male one. The difference in gender distribution in the Red River Delta in comparison to the other regions of the country is resulted by several reasons of which economic and cultural aspects are important factors. In economic aspect, the Red River Delta is a most concentrated area of many traditional handicraft villages; such villages attract a considerable number of labourers, especially female ones, and keep them to stay in rural area. In cultural respect, women in Red River Delta, especially ones who are over 40 years old, tend to stay in their hometown because they can work and take care of their children and parents [17]. Many researches have pointed out that women of over 40 years old age have least chance to migrate and to work in industrial zones or other non-agriculture sector in big cities. Therefore, their option to stay in their hometown makes the proportion of female labour force in the Red River Delta higher than in the other regions [18].

In the entire country, the proportion of female labourers working in informal sector is rather high. Most of them are working in rural area and agriculture [1]. In farm households of the Red River Delta, statistical data of the survey shows the similar result that female labourers still work in agriculture with higher proportion than male (Table 2). The proportion of female labour force staying in agriculture and rural area is still high because women in rural area of Vietnam still face several bariers in job finding. For example, they can recently participate in training courses but mostly short courses; supporting to find job after training courses is still limited. Besides, non-agriculture jobs of rural women are not very stable and they are not always able to access social security. That is why a large proportion of female labour 
force has to stick with agriculture [19].

Table 2

Gender distribution of labourers working in agricultural production

\begin{tabular}{|l|l|c|c|}
\hline \multicolumn{1}{|c|}{ Households } & \multicolumn{1}{c|}{ Sectors } & Male (\%) & Female (\%) \\
\hline \multirow{2}{*}{$\begin{array}{l}\text { In rice farming } \\
\text { households }\end{array}$} & Agriculture & 37.0 & 49.5 \\
\cline { 2 - 4 } $\begin{array}{l}\text { In pig farming } \\
\text { households }\end{array}$ & Non-Agriculture & 63.0 & 50.5 \\
\hline \multirow{2}{*}{$\begin{array}{l}\text { In clam farming } \\
\text { households }\end{array}$} & Agriculture & 38.4 & 41.3 \\
\cline { 2 - 4 } & Non-Agriculture & 61.6 & 58.7 \\
\cline { 2 - 4 } & Agriculture & 40.5 & 43.6 \\
\hline
\end{tabular}

Source: complied by the author based on hired farm labour survey in 2019.

In this part, the author analyzes reasons why farmers become hired labourers. The most common reason given by the labourers is that they work to increase family income $(62 \%)$. The second common answer is that the farmers think they are not able to find non-farm jobs because of their old age and low education. Almost $50 \%$ of the surveyed labourers suppose that their own farming does not cost much time so they have free time to do wage works (Fig. 5). Thus, increasing family income is still the main purpose of becoming wage labourers in agricultural production. Because of this purpose, the way farm households pay wage to and behave with labourers is an important factor to attract labourers, especially in peaking seasons when labour is usually scarce. Detailed analysis about payment method of farm households to labourers will be presented in the next part.

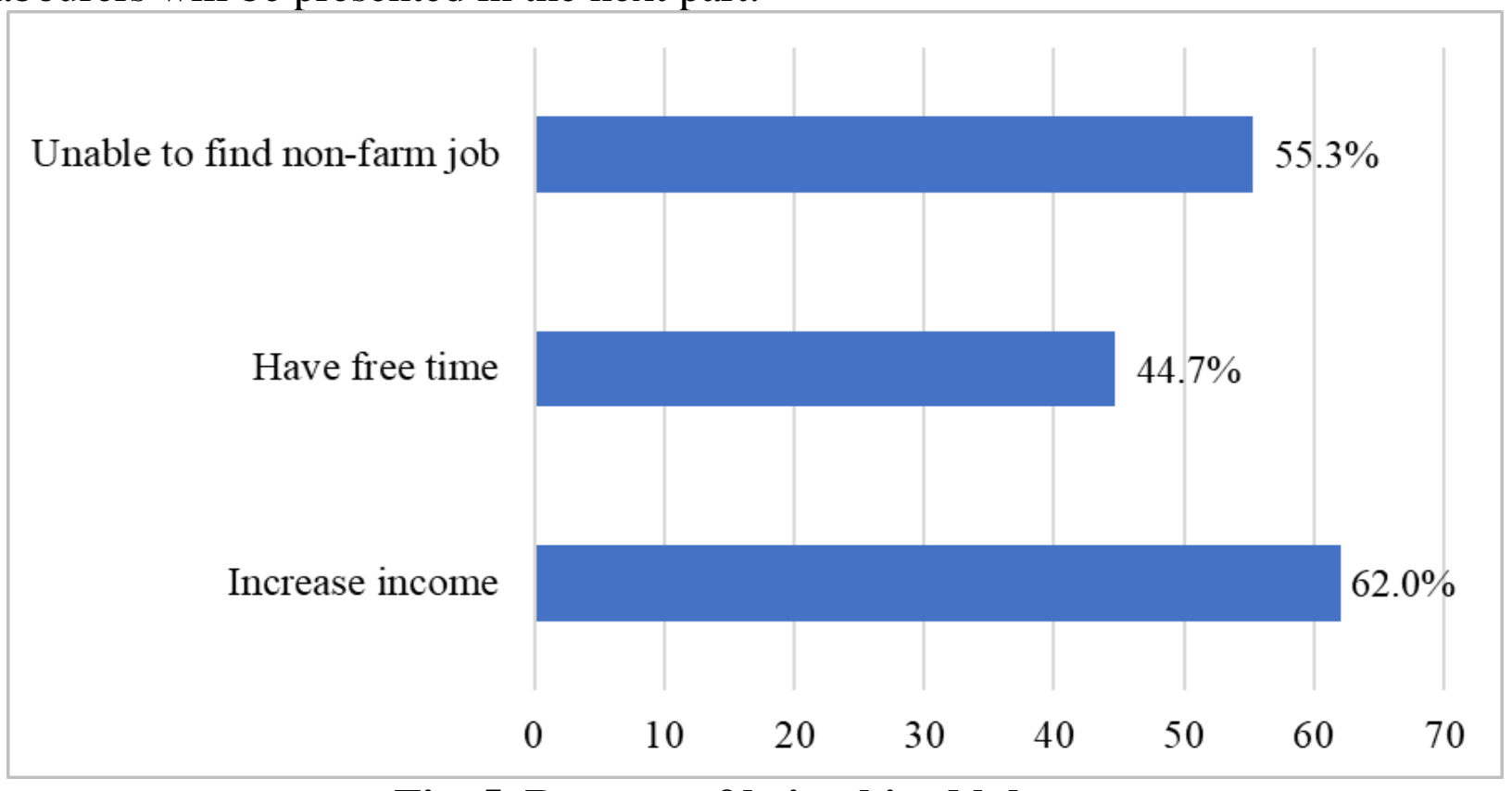

Fig. 5. Reasons of being hired laborer

Source: complied by the author based on hired farm labour survey in 2019.

Analysis of wage of hired farm labourers. Labor economic theory asserts that wage is the most important factor to measure labour value [20]. Theoretically, cash wage can be paid by daily, monthly basis or by piece wage, etc. During the field survey in Bac Ninh, Hai Duong and Thai Binh provinces, the author recognized that hired farm labourers usually receive 2 forms of payment, daily wage for seasonal 
workers and monthly wage for permanent workers. With seasonal workers, wage can be paid in many different forms depending on farming activities.

Daily wage. Daily wage is paid for seasonal hired workers exist only in rice and clam farming households. Generally, the average wage paid to hired labourers in the rice production is about $10 \mathrm{USD} /$ day. It ranges from 8.7 to $10.8 \mathrm{USD} /$ day depending on each certain activity. In comparison to the clam farming, the average wage of the rice production labourers is lower by $1.3 \mathrm{USD} / \mathrm{day}$. The difference comes from 2 reasons: firstly, clam farming activities usually are harder because workers have to work while dipping in water or have to move in wide area of 1 to 2 hectares; secondly, because profit of clam farming is much higher than the one of rice production, hired workers have reason to ask high wage.

Table 3

T-test for equality of daily wage means between rice and clam farming

\begin{tabular}{|c|l|c|c|c|c|c|}
\hline \multicolumn{2}{|c|}{ Description } & $\mathrm{t}$ & $\mathrm{df}$ & $\begin{array}{c}\text { Sig. } \\
\text { (2-tailed) }\end{array}$ & $\begin{array}{c}\text { Mean } \\
\text { Difference }\end{array}$ & $\begin{array}{c}\text { Std. Error } \\
\text { Difference }\end{array}$ \\
\hline \multirow{2}{*}{$\begin{array}{l}\text { Daily } \\
\text { wage }\end{array}$} & \begin{tabular}{l} 
Equal variances assumed \\
\cline { 2 - 7 } \\
\cline { 2 - 7 } \\
$\begin{array}{l}\text { Equal variances not } \\
\text { assumed }\end{array}$
\end{tabular} & -3.90 & 52.00 & 0.000 & -31.06 & 7.96 \\
\hline
\end{tabular}

Source: complied by the author based on hired farm labour survey in 2019.

In order to confirm the difference in the average daily wage for hired labourers working for rice and clam farming groups, the author performed T-test for the similarity of the 2 average wages. The result presented in Table 3 asserts that the difference is statistically significant between the two (sig <0.01). That truly reflects actual situation happening in labour market in general and in agricultural labour market in particular where labourers doing more difficult jobs need to be paid more.

Monthly wage. Pig farming and clam farming households also need hired laborers who are paid monthly wages. Basically, permanent workers in clam farming households are hired to guard clam plots and each of them receives wage of 152 to 260 USD each month. The most common wage is $152 \mathrm{USD} / \mathrm{month}$. The second common level is 175 USD. It also is the average wage of all hired labourers in the survey. This level is paid based on total working days of 30 days/month and working time from $6 \mathrm{pm}$ of the previous day to $6 \mathrm{am}$ of the next day morning. The labourers have to stay on guarding huts at night. Only $3.3 \%$ of labourers receive wage level of $260 \mathrm{USD} / \mathrm{month}$. In order to get this level, they not only guard clam plots but also do other works such as cleaning plots when clam dies, driving stakes in to ground and making net fence for clam plots.

In comparison to permanent labourers in clam farming households, the ones in pig farming households receive lower average salary of $160 \mathrm{USD} /$ month ranging from 130 to $183 \mathrm{USD} /$ month. The two common levels are 130 and 175 USD. Usually, a permanent labourer is hired to do almost all activities from foodstuff preparation, feeding, pigsty cleaning, to night guarding at pig farm. Therefore, wage level depends on the number of pigs he/she takes charge of. In addition, labourers staying at pig farms for night guarding are paid higher than the others. 


\section{Agricultural and Resource Economics: International Scientific E-Journal}

http://are-journal.com

In fact, permanent labourers in pig farms suppose that they used to be paid better. However, because fattening pig price has decreased fast and strongly since 2018 , in some certain time to only $1 \mathrm{USD} / \mathrm{kg}$, pig farming households must reduce farming size and cannot pay high wage. Many households even cannot hire labour but have to use family labourers or exchange with other households to cut down cost. However, many local labourers still opt to work for pig farming households because the works there are simple, do not require skills and working time is only 7 to 8 hours a day that they can arrange their time to do their own house works as well.

Voluntary social insurance. Generally, the system of social insurance includes 9 contents: health care, subsidy for sickness, unemployment subsidy, subsidy for old age, subsidy for working accident, subsidy for occupational disease, support for family, support for giving birth, support for disability, and subsidy in case of losing forester [21]. There are 2 main types of social insurance applied by the labour law of Vietnam which are compulsory insurance (5 contents) and non-compulsory insurance ( 2 contents). Basically, both types are to assure social security for labourers, especially when they become old and not be able to work. These types can be paid partly by the employers for their employees. That expresses a part of labour value of labourers. However, the basic difference is that the non-compulsory is for freelance workers, workers not having labour contract, and for hired labourers in agricultural production.

According to the Vietnamese Law of social insurance (2014), there are 6 optional methods for labourers to participate in a non-compulsory insurance contract: monthly payment, payment for every 3 months, payment for every 6 months, annually payment, one-time payment for several years (not beyond 5 years), and one-time payment for remaining years for people who reach age of receiving retirement salary but do not have enough time participating in the contract (less than 10 years). With these methods, the level of payment to a non-compulsory insurance contract ranges from 7 to $280 \mathrm{USD} /$ month. Because of sticking at the local authority level, the awareness of farmers including both hired labourers and farm householders about this type of social insurance is very ambiguous. A study result of the Ministry of Labour, War Invalids and Social Affairs of Vietnam in 2013 showed that among the people having social insurance contracts $58 \%$ of them participated in the contract because they knew about the policy through friends and relatives, only $20 \%$ of them got the information from local authorities [22]. The survey data of the author in Bac Ninh, Hai Duong and Thai Binh indicate that only $15 \%$ of the hired labourers know well about the non-compulsory social insurance (payment amount, number of years to pay, place to pay), $31 \%$ of them said that they had heard about this insurance, and the remaining $54 \%$ did not know about the existence of this insurance. Among the farm householders, $35 \%$ of them did not know anything about the noncompulsory social insurance (Fig. 6). The lack of awareness about this insurance among the hired labourers, householders and local authority officers leads to the situation in which the hired labourers suffer disadvantages, especially the ones having worked for long time in certain households. Such labourers have right to ask 
the householders to pay a part of the noncompulsory social insurance fee for them even though they have only verbal agreement.

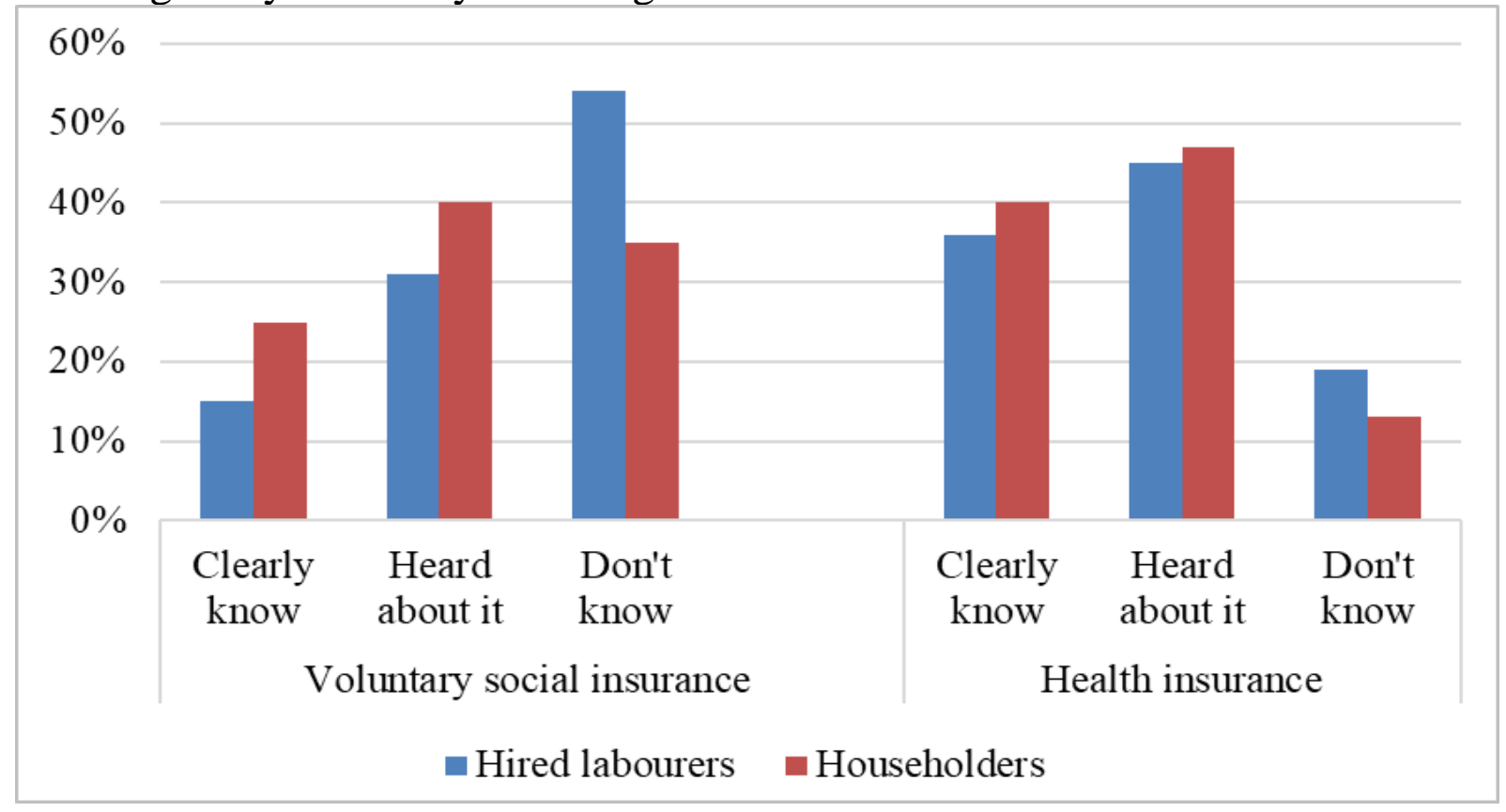

Fig. 6. Awareness of hired labourers about social and health insurance

Source: complied by the author on the basic of hired farm labour survey in 2019.

Among the 150 hired labourers surveyed, only 3 of them report that they are participating in the non-compulsory social insurance with the lowest payment level, 2 people are permanently working for pig farming households and 1 is permanent hired labourer working for a clam farming household. All 3 people are under 45 years old and participated in the insurance 3 to 5 years ago. The householders do not support them any for the insurance fee. From the fact that only minor proportion of hired labourers in agricultural production participate in non-compulsory social insurance, two aspects of an issue can be seen: for the first aspect, labourers do not fully understand the important role of social insurance for stabilizing their income when they become unable to work due to aging [22]; for the other aspect, policy execution including propaganda of non-compulsory social insurance to agricultural labourers and farm householders is till limited. When labourers get more understanding about this insurance, they will have more chance to negotiate with the householders hiring them to get support from such householders by providing them a part of the insurance fee. In fact, that is the right that permanent labourers working in pig and clam farming households own even they do not have labour contract but only verbal agreement.

Vocational training. Vocational training in this case study is called as workplace training, this is the way in which skills are upgraded and knowledge is acquired at the place of work. In other words, it can be conceptualized as the acquisition of knowledge or skills by formal or informal approaches that occurs in the workplace [23]. Workplace training mostly occurs through work-related interactions, and is generally described as contributing to the learning of both the individual employee and the organisation as a whole [23]. During the training, employees are familiarized 
with the working environment they will become part of. Employees also get a handson experience using equipment and working tools [24]. By improving skill through training, employees might also experience a sense of accomplishment, which can lead to increased their satisfaction and motivation with work. Moreover, well-trained employees become more skilled in their jobs so that they are less likely to make mistakes, resulting in higher efficiency and greater chance to gain a promotion [25].

It can be said that workplace training helps employers to get good human resource and increasing working efficiency and productivity. On the other hand, workplace training also helps labourers to enhance their working skills and then to increase labour value of themselves. Therefore, under value aspect, workplace training can be considered as a benefit receiving by hired labourers while working. In the labour market of the Red River Delta, workplace training is seen commonly in handicraft villages where householders are also seniors training junior workers [12]. For agricultural production, workplace training seems not to be common. Actually, all the hired labourers working in rice production households confirmed that they do not have any training during working in such households. They suppose that workplace training is not necessary because they already have good experience in rice farming from farming of their own households. For the hiring householders, they think that hired labourers in rice farming are seasonal employees who work for households from 5 to 20 days a month, thus households will not get benefit when spending time and even money on training them.

The proportion of the hired labourers having workplace training in clam farming is small, $16 \%$ (Fig. 7).

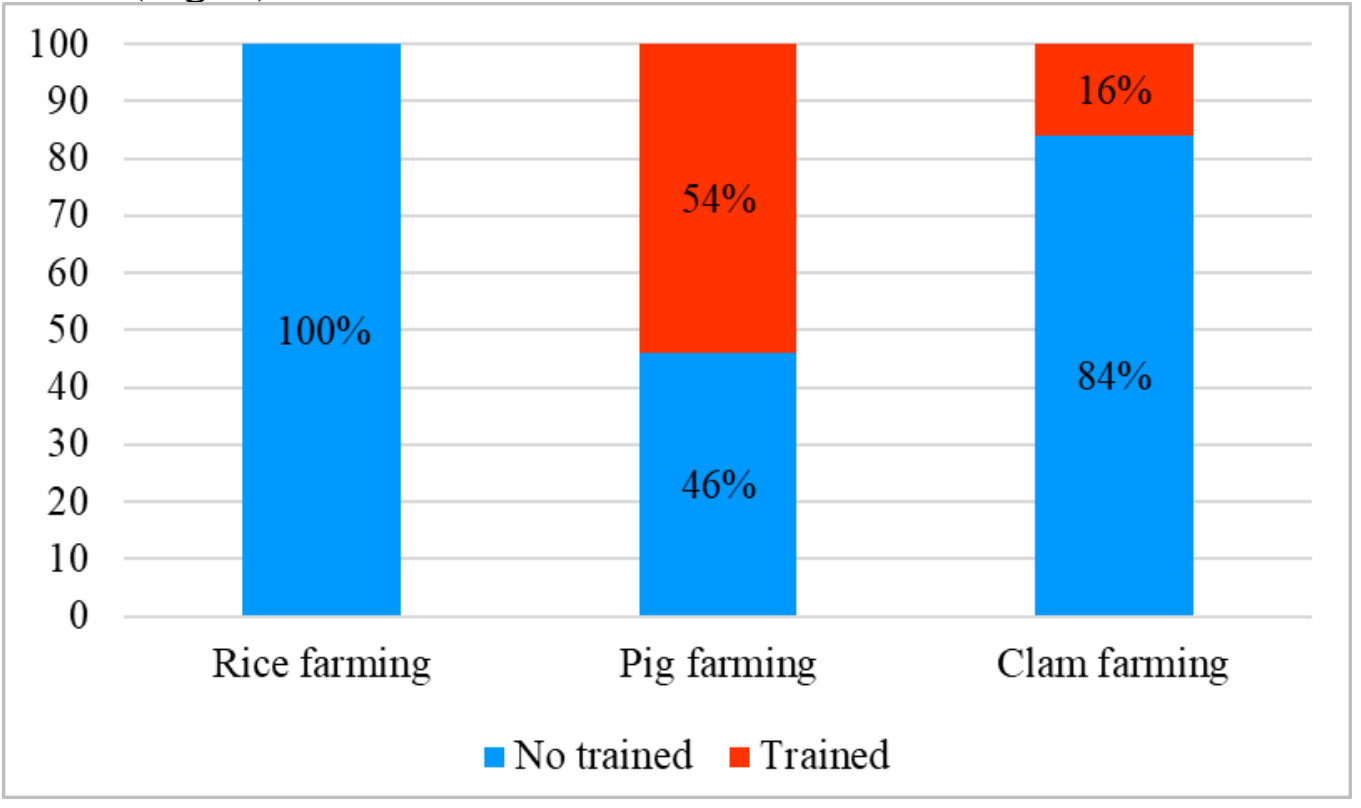

Fig. 7. Distribution of hired labourers in workplace training

Source: complied by the author based on hired farm labour survey in 2019.

Such labourers are mostly the ones who are new in clam farming activities. The householders train them or allow them to join in some training classes in order for them to know signs of clamp disease and treatment methods. Thus, they can observe clam diseases early and inform to the householders in time. Verbal training by the 
householders and most of training classes organized by local authorities are free of charge (62\% of the hired labourers have free training). However, there are $38 \%$ of the hired labourers sent to training classes, which are not for free, to learn some contents that the householders want and the householders pay all tuition fees. This fact is observed in households farming baby clam. Because the capital for this farming is huge, the householders want their labourers to fully understand techniques in farming baby clam to minimize losses.

The statistical data in Fig. 6 show that the highest proportion of hired labourers having training is in pig farming group (54\%). The pig farming householders think that the hired labourers need to understand clearly new techniques in large-scale farming in order to perform their works following technical requirements. Many big enterprises joining in the very potential market of industrial foodstuff and additives for pig farming have organized numerous training courses about pig farming techniques. Those courses are free of charge because such enterprises organize them to advertise their products. Therefore, there is a large number $(78 \%)$ of the hired labourers sent to such free training courses. Only $22 \%$ were sent by the householders to charged training classes for veterinary, prevention and treatment of pig diseases. Tuition fees for such classes are paid by the householders.

Briefly, except the seasonal hired labourers in rice farming households, the permanent hired labourers in pig and clam farming households have been trained by the householders to enhance their knowledge and working skills. Even though the number of trained labourers is not high, it is still enough to express the implied value they receive from the householders for their works. This value is totally different from wage or other remunerations because the labourers do not receive it in cash or in kind. They receive it in terms of knowledge and skill, instead. Knowledge is clearly valuable in the sense of securing success in practical life, or at least making success more likely [26].

Factors influencing wage of hired farm labourers. As mentioned in research methodology, the author applied a linear regression model to quantify impact of vocational training policy, social insurance policy and minimum wage regulation on wage of hired labourers in agricultural production. Vocational training is measured by the number of times a labourer attends training courses. In my sample, the highest time found is 4 and the lowest time is zero. Social insurance is a dummy variable that equal to 0 if a labour does not involve in purchasing this insurance and equal to 1 vice versa. In this survey, we observe only $31.7 \%$ of respondents spend their money to buy social insurance. For what concern to wage regulation, we apply "minimum wage" variable to quantify awareness of hired labourers about minimum wage regulation. This parameter is a dummy which receives 0 value if the interviewed labourers report that he/she does not know about minimum wage policy and 1 value the other way around. Our descriptive results indicate that a large proportion $(66.7 \%)$ of surveyed labourers does not aware about minimum wage.

Results of linear regression model illustrate that gender, educational level, participating in vocational training courses, and perception of minimum wage have 
statically significant effects on wage of hired labourers in agricultural sector. Within the sample, average wage of a labourer is 5.22 million Vietnam dong per month (equals to 240 USD). However, female labourers receive a wage rate of 4.94 million Vietnam dong, it's about 20 USD less than male labourers' wage rate. In our linear regression model, the wage gap between male and female labourers is 298.250 Vietnam dong which is equivalent to 15 USD (Table 4).

Table 4

Results of the linear regression model

\begin{tabular}{|l|c|c|c|}
\hline \multirow{2}{*}{\multicolumn{1}{|c|}{ Variation }} & \multicolumn{2}{c|}{ Unstandardized Coefficients } & \multirow{2}{*}{ Sig. } \\
\cline { 2 - 3 } & $\beta$ & Std. Error & .088 \\
\hline 1. Constant & $99.831^{*}$ & 36.252 & .068 \\
\hline 2. Gender & $298.250^{*}$ & 49.974 & .441 \\
\hline 3. Age & -313.148 & 593.940 & .051 \\
\hline 4. Education & $215.272^{*}$ & 75.467 & .049 \\
\hline 5. Vocational training & $66.602^{* *}$ & 17.786 & .398 \\
\hline 6. Social insurance & 921.264 & 1181.959 & .029 \\
\hline 7. Minimum wage & $111.916^{* *}$ & 14.327 & - \\
\hline \multicolumn{1}{|c|}{ R-square 0.64 } & F 213.307 & Sig 0.030 & . \\
\hline
\end{tabular}

Note. ${ }^{*}$ Coefficient is significant at the 0.05 level; $*$ Coefficient is significant at the 0.1 level.

Source: complied by the author based on hired farm labour survey in 2019.

Many employment studies in rural area of Vietnam pointed out that vocational training for rural labour is considered as one of the most important solutions to enhance labour quality in this area. Vocational training needs be based on actual demands of labourers as well as of society and combined with employment. Socialization of vocational training is an important policy to increase the efficiency of the training. Besides, it needs to better propagate and guide rural labourers about vocations because many of them are still lack of knowledge about vocational direction. This lack of understanding about vocational training courses results in agricultural labourers missing out on opportunity to enhance their skill to get higher wage. The model shows that with one time higher in attending vocational training, a hired labourer can earn 66.602 Vietnam dong (3 USD) more than his/her monthly wage. In other words, employers tend to pay labourers higher wages if they know these labourers involve in vocational training courses more than others.

As for perception of minimum wage policy, the finding is as expected. The author finds that labourers who know the existence of this regulation will be paid higher than those do not recognize it. This is because the perception brings labourers more power to negotiate their wage with employers. The regression model predicts that understanding about minimum wage policy will increase 111.916 Vietnam dong (5 USD) in wage for labourers. Despite the fact that minimum wage policy is applied only for labourers who work under written contracts, the awareness of them about this policy is still important to improve the collective bargaining for their wage.

Conclusions. 1. The beginning part of this paper draws an overview picture of Vietnamese Government policies for labourers who work in wage labour market. In the second part, hired farm labourers are described specifically. With the common 
age of 40 to 55 years old, the labourers (both seasonal and permanent) usually have 2 to 4 years working for the farm households at the survey moment. According to their opinion, such long time working for a certain household helps them to keep good relation with the householder, to have stable job and to save time for looking for new employment. Female hired labourers are observed with higher proportion than male ones in agricultural production.

2. The wage of hired labourers in farm households is paid in two methods: daily wage for seasonal labourers and monthly wage for permanent ones. The daily wages apply for farming activities which last within a few days such as manual transplanting, manual harvesting in rice farming or clam harvesting. The daily wage may be paid in piece for activities such as soil preparation and spraying pesticide. Among rice farming activities, manual transplanting and manual harvesting are paid the highest wage. In clam farming, labourers doing harvesting receive the highest wage which is 2 USD higher than the highest wage in rice farming. The monthly wage is common for labourers in pig farming and clam plot guarding. The wage is counted for 30 working days. In comparison the labourers in pig farming households, the wage of labourers guarding clam plots is about $20 \mathrm{USD} / \mathrm{month}$ higher. However, comparing to average monthly wage of an agricultural labourer in rural area of Vietnam, the wage of labourers in pig and clam farming groups is 10 to $30 \mathrm{USD} / \mathrm{month}$ higher.

3. Minimum wage, social insurance and vocational training policies have been issued in order to support labourers to improve their wage. By the law, minimum wage regulation is applied for labour working under written contracts. Whereas, vocational training policy focuses on enhancing work skill for rural labourers. In this paper, minimum wage and vocational training policies are found to have statistically significant impact on wage of labourers in agricultural sector. The author identifies that attending vocational training and understanding of minimum wage will increase the chance for labourers to obtain higher wage.

Due to the limitation of time and finance, this research focuses on analyzing primary data collecting from only 150 hired farm labourers in the Red River Delta of Vietnam. In the future, the author expects to conduct more survey in the whole country so that the research findings can provide more insights of impact of labour policies on rural wage of hired farm labourers who live and work in many other regions of the country. Based on these new findings, the author also expects to propose more valuable recommendations to engage hired farm labourers into the consideration of Vietnamese Labour Code.

\section{References}

1. Vietnam General Statistics Office (2018), Statistical Year Book, Hanoi Statistical Publishing House, Hanoi, Vietnam.

2. Nguyen, N. T. H., Lebailly, P. and Nguyen, D. M. (2019), Labor division in pig farming households: an analysis of gender and economic perspectives in the Red River Delta Vietnam. International Journal of Economics and Financial Issues, vol. 9, no. 1, pp. 183-192. https://doi.org/10.32479/ijefi.7274. 


\section{Agricultural and Resource Economics: International Scientific E-Journal}

http://are-journal.com

3. Trinh, T. V. (2018), Policies for labour's salary to promote their emotion on work. Journal of Industry and Trade in Vietnam, available at: http://tapchicongthuong.vn/bai-viet/doi-moi-chinh-sach-tien-luong-tao-dong-luc-lamviec-cho-nguoi-lao-dong-mot-so-van-de-trao-doi-29155.htm.

4. Nguyen, T. D. (2017), The growth of wage and labor productivity in Vietnam. Vietnam Institute for economics and policy research and Jica Vietnam, Hanoi, Vietnam, available http://vepr.org.vn/upload/533/fck/files/1_\%20Full\%20ENG_20170912_0615pm.pdf.

5. International Labour Organization (2016), 2016 Report on Informal Employment in Vietnam, Hong Duc Publishing House Vietnam, Hanoia, Vietnam, available at: https://www.ilo.org/wcmsp5/groups/public/---asia/---ro-bangkok/---ilohanoi/documents/publication/wcms_638330.pdf.

6. Tuong, M. D. (2016), Shifting of labor structure in the Red River Delta. Working paper presented at the FAO-IFAD-ILO Workshop on Gaps, trends and current research in gender dimensions of agricultural and rural employment, Hanoi, Vietnam.

7. Oya, C. and Pontara, N. ed. (2015), Rural wage employment in developing countries: theory, evidence, and policy, 1st ed, New York Taylor \& Francis Group, Hoboken, USA.

8. Engelhardt, G. V. and Purcell, P. J. (2021), The minimum wage and annual earnings inequality. Economics Letter, vol. 207, 110001. https://doi.org/10.1016/j.econlet.2021.110001.

9. Kassa, G. (2016), Determinants of job satisfaction among agricultural extension workers in Southwest Ethiopia. American Journal of Agriculture and Forestry, vol. 4, is. 5, pp. 112-117. https:// doi.org/10.11648/j.ajaf.20160405.11.

10. Schmillen, A. D. and Packard, T. G. (2016), Vietnam's labor market institutions, regulations, and interventions: helping people grasp work opportunities in a risky world. Policy Research, Working paper no. 7587. World Bank, Washington, DC. World Bank. https://openknowledge.worldbank.org/handle/10986/23928.

11. Buckley, J. (2017), Is Vietnam minumum wage structure sustainable. Industrialization and Urbanization in Vietnam. Working paper no. 38, East Asian Development Network.

12. Nguyen, N. T. H., Lebailly, P. and Nguyen, D. M. (2018), The Red River Delta, Vietnam: how does industrialization change the use of labor in agricultural production at farm households? The Asian International Journal of Life Sciences, vol. 27 , is. 2 , pp. $1-18$.

13. Le, H. T. V. (2018), Gender, Doi Moi and Coastal Resource Management in the Red River Delta, Vietnam in Gender and Natural Resource Management. Livelihoods, Mobility and Interventions, eds B. P. Resurreccion and R. Elmhirst. TJ International Ltd, London, UK.

14. Trung, L. D. and Oostendorp, R. H. (2016), Regional labor market integration, shadow wages and poverty. World Development, vol. 89, pp. 34-56. 


\section{Agricultural and Resource Economics: International Scientific E-Journal}

http://are-journal.com

https://doi.org/10.1016/j.worlddev.2016.07.011.

15. Asian Development Bank (2012), Improving vocational training for Vietnamese rural workers, available at: https://www.adb.org/sites/default/files/project-document/176144/vie-rural-workerstraining-report.pdf.

16. International Labour Organization (2011), Research report on rural labour and employment in Viet Nam, available at: https://www.ilo.org/hanoi/Whatwedo/Publications/WCMS_171760/lang-en/index.htm.

17. Nguyen, N. T. H. and Lebailly, P. (2018), Impact of wage employment in agriculture production on labor satisfaction in the Red River Delta Vietnam. International Journal of Applied Business and Economic Research, vol. 16, is. 2, pp. 391-401.

18. Narciso, G. (2015), Labor and migration in rural Vietnam. Working paper no. 2015/095, UNU-WIDER, Helsinki, Finland, available at: https://www.wider.unu.edu/sites/default/files/wp2015-095.pdf.

19. Nguyen, T. Q. and Le, P. H. (2016), The situation of rural labors, the impact of vocational training, employment, and income of rural laborers in Vinh Long province. Can Tho University Journal of Science, vol. 43, pp.51-59. https://doi.org/10.22144/ctu.jvn.2016.081.

20. Robinson, J. A. and Subrick, J. R. (2020), Why did Smith suggest a labor theory of value? Journal of Economic Behavior \& Organization, vol. 184, pp. 781787. https://doi.org/10.1016/j.jebo.2020.08.040.

21. Dao, A. (2020), What it means to say "I Don't have any money to buy health insurance" in rural Vietnam: how anticipatory activities shape health insurance enrollment. Social Science \& Medicine, vol. 266, 113335. https://doi.org/10.1016/j.socscimed.2020.113335.

22. Luu, T. Q. (2015), Policy implications for extending social security system in Vietnam toward 2020, MOLISA, Hanoi, Vietnam, available at: http://ilssa.org.vn/vi/news/co-so-ly-luan-va-thuc-tien-xay-dung-chinh-sach-khuyenkhich-tham-gia-bao-hiem-xa-hoi-10.

23. Cacciattolo, K. (2015), Defining workplace learning. European Scientific Journal, vol. 1, pp. 243-250.

24. Chi, H., Vu, T-V., Vo-Thanh, T., Nguyen, N. P. and Nguyen, D. V. (2020), Workplace health and safety training, employees' risk perceptions, behavioral safety compliance, and perceived job insecurity during COVID-19: data of Vietnam. Data in Brief, vol. 33, 106346. https://doi.org/10.1016/j.dib.2020.106346.

25. Olakojo, A. S. (2016), Seasonal labor market rigidities: impact on farm employment and wages in Nigeria. Economic of Agriculture, vol. 63, is. 4, pp. 11231140. https://doi.org/10.5937/ekoPolj1604123O.

26. Feuerbacher, A., McDonald, S., Dukpa, C. and Grethe, H. (2020), Seasonal rural labor markets and their relevance to policy analyses in developing countries. Food Policy, vol. 93, 101875. https://doi.org/10.1016/j.foodpol.2020.101875. 
Citation:

Стиль-ДСТУ:

Nguyen Thi H. N. Vietnam labour policies and its impact on rural wages: an experience from hired farm labourers in the Red River Delta. Agricultural and Resource Economics. 2021. Vol. $7 . \quad$ No. $4 . \quad$ Pp. 42-61. https://doi.org/10.51599/are.2021.07.04.03.

Style-APA:

Nguyen Thi, H. N. (2021), Vietnam labour policies and its impact on rural wages: an experience from hired farm labourers in the Red River Delta. Agricultural and Resource Economics, vol. 7, no. 4, pp. 42-61. https://doi.org/10.51599/are.2021.07.04.03. 